Portland State University

PDXScholar

1979

\title{
An Investigation of Client Fluency Maintenance Between 1972-1977 at Portland State University
}

Pricilla Lynn Ginter

Portland State University

Follow this and additional works at: https://pdxscholar.library.pdx.edu/open_access_etds

Part of the Speech and Hearing Science Commons, and the Speech Pathology and Audiology Commons

Let us know how access to this document benefits you.

\section{Recommended Citation}

Ginter, Pricilla Lynn, "An Investigation of Client Fluency Maintenance Between 1972-1977 at Portland State University" (1979). Dissertations and Theses. Paper 2677.

https://doi.org/10.15760/etd.2673

This Thesis is brought to you for free and open access. It has been accepted for inclusion in Dissertations and Theses by an authorized administrator of PDXScholar. Please contact us if we can make this document more accessible: pdxscholar@pdx.edu. 
AN ABSTRACT OF THE THESIS OF Priscilla Lynn Ginter for the Master of Science in Speech Communication, with an emphasis in Speech Pathology/ Audiology, presented May 2, 1979.

Title: An Investigation of Client Fluency Maintenance Between 1972-1977 at Portland State University.

APPROVED BY MEMBERS OF THE THES IS COMMITTEE:

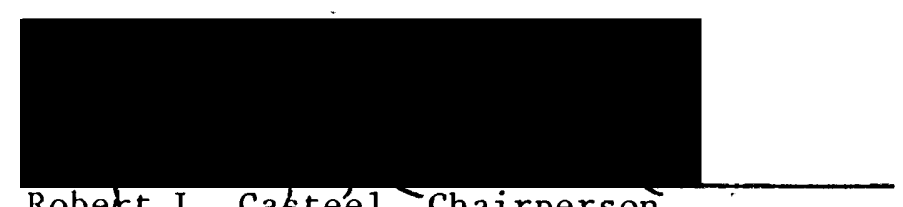

Robekt L. Caktéel, Chairperson
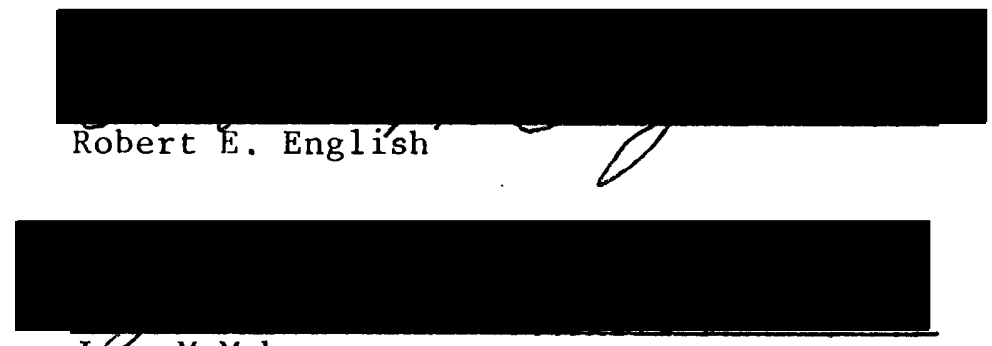

Joan McMahon

The use of so many different therapeutic approaches to stuttering raises frequent questions about. methodology and treatment. Confidence in a methodology and treatment approach depends upon follow-up research conducted with systematic analysis of the individuals prior to treatment and following treatment.

The purpose of this study was to conduct a follow-up evaluation on R. L. Casteel's Four Stage Stuttering Program at Portland State University and to examine the degree of maintained fluency in relation to entering baseline, time in program, and exit stage. 
Twenty-two subjects were seen who had terminated the program in Stage III, Stage IV, or Self-Maintenance. The length of time elapsed since these subjects terminated from clinic ranged from one to five years. They had received one to six terms of clinic.

The results of this research indicate approximately 50 percent success rate with Casteel's Four Stage Stuttering Program. The length of time in clinic and the length of time elapsed since termination were not significant factors in fluency retained at follow-up. Also the stage (Stage III, Stage IV, or Self-Maintenance) in which an individual terminated the program was not significant to fluency retained at follow-up. The research does indicate a significant relationship between severity at baseline and severity at follow-up, indicating a client with a higher severity at baseline may have a higher severity at follow-up.

The percentage of the twenty-two individuals who participated in this study and demonstrated improvement in point scores was 81.8 percent. The percentage of individuals who demonstrated movement to a lower severity category was 68.1 percent. The percentage of subjects who demonstrated normal fluency at follow-up was 59.1 percent, with 50 percent of the subjects demonstrating movement to normal fluency from a higher level of severity. The results indicate 68.1 percent of the twenty-two subjects who participated in this study had acquired some lasting skill in knowing what to do to be fluent. 


\section{AN INVESTIGATION OF CLIENT FLUENCY MAINTENANCE}

\section{BETWEEN 1972-1977 AT PORTLAND STATE}

\section{UNIVERSITY}

\section{by}

PRISCILLA LYNN GINTER

A thesis submitted in partial fulfillment of the requirements for the degree of

\section{MASTER OF SCIENCE IN SPEECH COMMUNICATION: \\ with an emphasis in SPEECH PATHOLOGY/AUDIOLOGY}

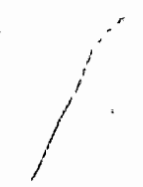

Portland State University

1979 
TO THE OFFICE OF GRADUATE STUDIES AND RESEARCH:

The members of the Committee approve the thesis of Priscilla Lynn Ginter presented May 2, 1979.

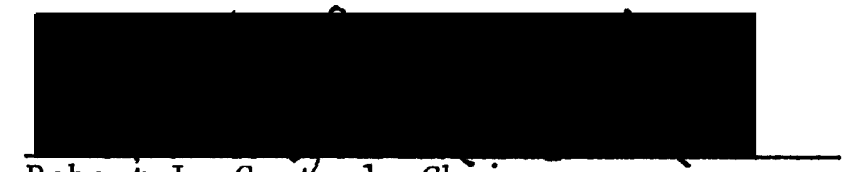

Robert L. Casteel, Chairperson
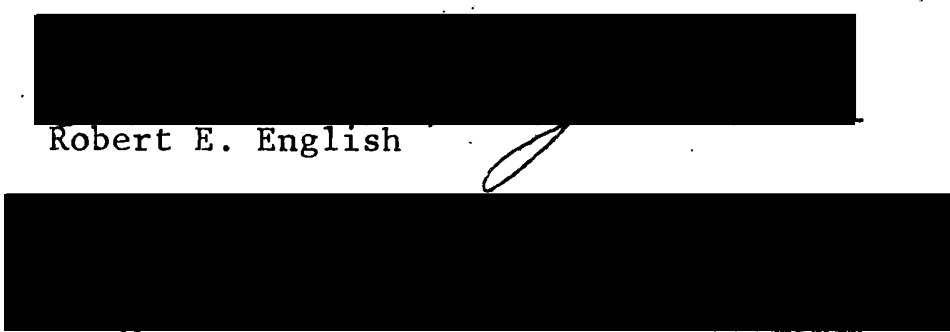

Joakn McMahon

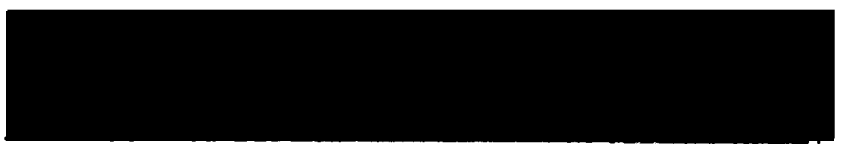

Linda Nek1ason

APPROVED :

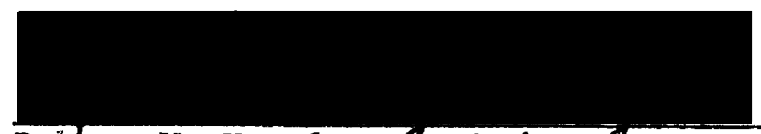

Robert W. Vogelsanf, Chairmag,

Department of Speech Communlcation

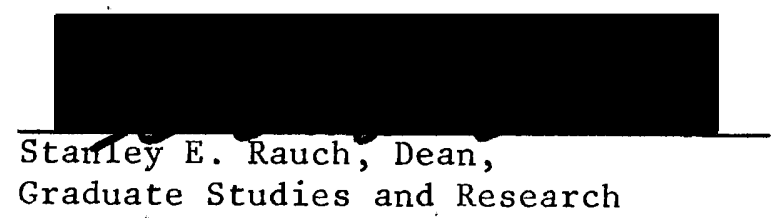




\section{ACKNOWLEDGMENTS}

Many people have been involved, boțh directly and indirectly, in this research and $I$ am very grateful for their help and support.

First, I would like to thank my committee chairman, Dr. Robert L. Casteel for his continued support and patience with me during this research. I thank Dr. Robert E. English.for being on my committee and his advice and guidance. I thank Joan McMahon for being on my committee and for providing friendship and guidance throughout my undergraduate and graduate studies. Joan, I wouldn't have made it without you!

A very special thanks to Dr. Hegrenes for his interest and counsel on the statistical preparation of this study. A special thanks to Carol Kimball who was very helpful in the early beginnings of this research.

I also would like to thank my roommate, Lou Ann McCoy, for putting up with me for the past two years. Your friendship is treasured dear $1 y$.

Fina1ly, I would like to thank my mother and father for their constant support throughout my undergraduate and graduate education. You were always there when I needed a shoulder to cry on or someone to 1isten to my gripes. Finishing this study was the best retirement present I could think of. Happy retirement! 
TABLE OF CONTENTS

PAGE

ACKNOWLEDGMENTS ................... . . iii

LIST OF TABLES ....................... vi

CHAPTER

I INTRODUCTION ....................... 1

Purpose . . . . . . . . . . . . . 3

Definition of Terms ........... 3

II REVIEW OF THE LITERATURE . . . . . . . . . . 6

III METHODS .................. . . . 16

General Plan ............ 16

Subjects

Scheduling Procedure

Instrumentation

Instrumentation Reliability and Validity

Nature of the Testing Environment

Speaking Tasks

Scoring Procedure

Examiner Reliability

Analysis of Data

IV RESULTS AND DISCUSSION . . . . . . . . . . 24

Results.............. . . 24

Discussion ............ . . 33

$\mathrm{V}$ SUMMARY AND IMPLICATIONS ........... 40

Summary . . . . . . . . . . . . 40

Implications . . . . . . . . . . 41

Clinical

Research 
PAGE

SELECTED BIBLIOGRAPHY . . . . . . . . . . . . . . . . . . 43

APPENDICES . . . . . . . . . . . . . . . . . . . 46

A LETTER OF INQUIRY . . . . . . . . . . . . . . . . . 46

B INFORMATION CARD . . . . . . . . . . . . . . 47

C CLASSIFICATION OF OTHER PROGRAMS ........... 48

D. STUTTERING SEVERITY INSTRUMENT EVALUATION SCALE . . . 49

E READING PASSAGE USED FOR SSI . . . . . . . . . . 50

F RULES FOR SCORING PHYSICAL CONCOMITANT PORTION OF STUTTERING SEVERITY INSTRUMENT . . . . . . . . . 51

G REVISED SEVERITY RATINGS FOR SSI PORTLAND STATE UNIVERSITY . . . . . . : . . . . 54

H COMPOSITE RESEARCH RESULTS . . . . . . . . . . 55 
LIST OF TABLES

I PROGRAM STAGE AT TERMINATION AND SEVERITY SCORES . . . 25

II F-TEST ANALYSIS OF VARIANCE FOR TERMINATION STAGES . . 26

III t-TEST FOR DIFFERENCES BETWEEN MEANS FOR TERMINATION STAGES . . . . . . . . . . . . 26

IV TERMS IN MANAGEMENT AND SEVERITY SCORES . . . . . . . 28

V F-TEST ANALYSIS OF VARIANCE FOR TERMS IN MANAGEMENT . . . . . . . . . . . . . . . . 29

VI t-TEST FOR DIFFERENCES BETWEEN MEANS FOR TERMS IN MANAGEMENT . . . . . . . . . . . . . . . . 29

VII TIME ELAPSED SINCE TERMINATION AND SEVERITY SCORES . . 31

VIII VARIATION IN SEVERITY SCORES BETWEEN BASELINE AND FOLLOW-UP . . . . . . . . . . . . . 32

IX t-TEST -FOR DIFFERENCES BETWEEN MEANS FOR BASELINE AND FOLLOW-UP SEVERITY SCORES • • • . • . • • • . 33

$X$ COMPARISONS OF NORMAL RATINGS AT FOLLOW-UP AND SEVERITY RATINGS AT BASELINE . . . . . . . . . . 34 
CHAPTER I

INTRODUCTION

The disorder of stuttering was defined by Wingate (1964) as ". . a disorder in the rhythm and fluency of speech which specifically involves repetitions and prolongations of the smaller speech elements, such as sounds, syllables and words of one syllable." No one area in the realm of speech pathology has attracted more attention or received more concern than the disorder of rhythm called stuttering. Tremendous amounts of research have been done to acquire insight into the nature of stuttering, and many aspects still remain a mystery. Researchers disagree on the etiology, onset, development, and specifically the treatment for stuttering. Resulting from this disagreement among researchers, many therapeutic approaches to stuttering intervention have developed over the years. The ones that remain in existence remain so because some success in reducing disfluency is established during intervention. The use of so many different thera- $\cdots$ peutic approaches frequently raises questions regarding methodology and treatment. Andrews and Ingham (1972a) stated the ". . lack of preparedness to systematically measure progress and assess the outcome of treatment may have led to the present crisis in confidence over the efficacy of treatment for stuttering."

There is an abundance of theories and therapy techniques in the literature, including the use of rhythmic stimulation techniques, 
shadowing, delayed auditory feedback and prolonged speech, masking, negative practice, anxiety reduction, operant conditioning, and psychotherapy (Ingham and Andrews, 1973). Whichever therapy mode is selected, reports of treatment results in the literature are less than satisfactory; little systematic analysis of therapeutic results outside the treatment situation or results over extended periods of time is mentioned. The need for more long-term follow-up and longitudinal studies is being expressed by more and more researchers (Bloodstein, 1961; Sheehan and Martyn, 1966; Cooper, 1972).

Regression following termination of intervention has always been a significant problem (Prins, 1970). The degree of regression found at varying times of follow-up may reveal additional information to be used in examining the efficacy and possible need for modification of an intervention program. To do this, some form of standardized measurement would need to be utilized prior to intervention, and at the time of follow-up.

The program developed for the modification of stuttering behavior in the Speech and Hearing Sciences Program at Portland State University has incorporated the use of a standard assessment tool, the Stuttering Severity Instrument (Riley, 1972) (Appendix D). This instrument has been utilized since the Fall of 1972, prior to the start of intervention. To date, there has been only sporadic followup on former clients of this program. 
PURPOSE

The primary purpose of this study was to conduct a follow-up evaluation of the Portland State University stuttering program, examining the degree of maintained fluency in relation to entering baseline, time in program, and exit stage of former clients.

The following questions were investigated:

1) Did the stage in which the client left the program have any bearing on fluency retained?

2) Did the number of terms of clinic a client received have any bearing on fluency retained?

3) Did the length of time elapsed since the client terminated the program have any bearing on fluency retained?

4) What relationship exists between baseline and follow-up scores?

5) What percentage of the subjects maintained fluency improvement within the established normal limits of 0 to 8 on the Stuttering Severity Instrument scale?

\section{DEF INITION OF TERMS}

For the purposes of this study the following terms are defined as :

Audible distractions: Includes any sound which accompanies a stuttering occurrence such as whistling noises, sniffing, blowing, and clicking sounds. Also, "verbal junk" such as nonsyntactical components, rephrasing and audible breathing which may or may not accompany a stuttering occurrence (Riley, 1972).

Baseline: The score given to the individual's behavior prior to intervention. 
Castee1's Four Stage Stuttering Program: A behavior modification program for the treatment of stuttering which utilizes four stages in which various vocal components are first sacrificed and then reinstated (Casteel and McMahon, 1978).

Distracting facial grimaces: Any abnormal movement or tension about the face associated with the moment of stuttering. Pressing lips tightly together, protruding tongue, tensing jaw muscles, blinking eyes, etc. (Riley, 1972).

Distracting head movements: Consists of turning the head away from the listener to avoid eye contact or for other reasons, head bouncing, or abnormal posturing (Riley, 1972).

Distracting movements of extremities: Body movement such as shifting the torso, foot-tapping, or excessive movement of arms and legs, or the lack of movement as in tensing (Riley, 1972).

Exit stage: Stage at which the individual terminated the program of intervention or was terminated.

Fleeting: Stuttered instance of less than one-half second.(Kimba11, 1975).

Follow-up: Evaluation of individual's behavior following termination of intervention.

Physical concomitants: A category which includes both visible and audible phenomena that may or may not accompany stuttered speech but are found distracting to the listener (Riley; 1972).

Self-maintenance: Final part of Casteel's Stuttering Program in which less dependence is placed upon the clinician and more dependence is placed upon the client's own ability to do what he needs to do to 
talk fluently (Casteel and McMahon, 1978).

Stuttering: A disorder in the rhythm and fluency of speech (Wingate, 1964).

Stuttering instance: Any visible stoppages or audible prolongation or repetition of a sound or syllable with associated tension (Riley, 1972).

Stage I (Stretch and Flow): Characterized by prolongation of words using closed juncture, monotone, extreme breathiness, and loose articulation (Castee1, 1976).

Stage II (Increased Breath): Rate is reinstated, but the client must maintain exaggerated breathiness, closed juncture, monotone, and loose articulation (Casteel, 1976).

Stage III. (Reduced Breath): Loudness and pitch are reinstated, normal rate is maintained, there is small amount of breathiness, and articulation remains somewhat loose (Casteel, 1976).

Stage IV (Easy.Talking): Rate, loudness, quality, pitch, and articulation all are reinstated for normal talking (Casteel, 1976).

Transfer: Spread or generalization of newly learned skills to various speaking situations and daily routine (Casteel and McMahon, $1978)$ 
Tremendous amounts of research have been done on the disorder called stuttering. Studies in various areas have examined the nature of the disorder, time of onset, and different therapeutic approaches. One area which is of great importance is follow-up research where the effects or consequences of different therapeutic programs are studied. Research in the area of follow-up is basically one of two types, although they do overlap to some extent. The first type is immediate follow-up, or when the immediate effects of a treatment program are evaluated. The second type of follow-up is long-range, where the permanence or maintained effects of the treatment program over time are evaluated. Both types are of importance not only to the person who stutters but also to the clinician and the program center which implements the treatment.

Immediate follow-up research is done most often to determine efficacy of a treatment program at its completion and/or to contrast or compare the effects of two treatment programs at completion. Longrange follow-up is used when the durability of change is being evaluated. Other variables viewed include the different aspects of the treatment programs. From long-range follow-up the durability of treatment effects and, at times, therapeutic modifications are determined. As with immediate follow-up, long-range follow-up is often 
used to contrast and compare two treatment programs (Prins, 1970).

Research in the area of follow-up is far from adequate due to lack of specific criteria for measurement of treatment effects and difficulties encountered with case follow-up procedures which have hampered many studies. (Prins, 1970; Wingate, 1971).

Nevertheless, several studies have explored the effects of therapeutic programs. Many studies have reported the immediate effects of various treatment programs upon speech responses by stuttering individuals (Cherry and Sayers, 1956; Sheehan and Voas, 1957; Franse11a and Beech, 1965; Shames, Egolf, and Rhodes, 1969; Prins, 1970; Ingham and Andrews, 1971; Andrews" and Ingham, 1972b; Curlee and Perkins, 1973; Ryan and Van Kirk, 1974; Prins, 1976).

Studies which have attempted to assess the broader scope or long-range effects of treatment programs are not as numerous as those studies which have evaluated only the immediate effects.

The classic study done by Van Riper (1958) was one of the first studies to look at the long-range effects of a stuttering treatment program. Over the course of more than twenty years Van Riper recorded detailed clinical descriptions of his methods and results in stuttering therapy. His aim in this study was to vary his therapeutic methods from year to year, keeping regular records of results, instituting a five-year follow-up program so as to evaluate the results of his therapy. In his study he gave a year-to-year summary discussing modifications of treatment and the results obtained at termination of treatment.

Van Riper (1958) did not use a formal measurement technique for 
assessing the severity of stuttering. Subjects were chosen for the therapy program if the examiner judged their stuttering to be severe and prognosis unfavorable. Criteria used at the end of therapy to determine success. included:

- 1) that the individual speak better than the
examiner in all situations, 2) the individual not avoid
words or speaking situations, 3 ) the individual's stut-
tering must not be interfering with his social or voca-
tional adjustment, and 4 ) his stuttering must present
no concern to himself or others.

At the termination of the therapy program a written description of the individual's speech was made by the examiner. During follow-up these written descriptions were used for comparison with the behaviors the individual displayed. From his research on the long-range effects of his therapy program, Van Riper suggested that regression was a significant problem.

More recent research in the area of follow-up has shown that studies have incorporated more formal measurements for rating the severity of stuttering, thus reducing the amount of examiner bias.

A study done by Gregory (1972) included formal evaluation and measurement of the subjects nine months prior to management, again just before management began, at the end of a nine-month program, and at a follow-up period nine months after termination from the program.

The therapy program employed by Gregory was essentially an avoidance and anxiety reduction program based on concepts of learning theory. The study was based on seventeen adult stutterers. Each subject was rated for severity by listeners using the Young's Rating Analyzer (Gregory, 1972). Listener's scaled severity of stuttering on a nine-point equally appearing interval scale. From these ratings 
subjects were divided into two groups, the "less severe" and "more severe." Subjects were rated on both reading and speaking tasks, which resulted in a reading severity rating and a speaking severity rating. A derived reading-speaking severity rating also was calculated since stutterers usually wish to improve in both spontaneous speech and reading; thus it is a measure of overa11. improvement. The Stutterer's Self-Rating of Reactions to Speech Situations (Johnson, Darley, and Spriesterbach, 1963) and the Iowa Scale of Attitudes Toward Stuttering (Johnson et al., 1963) were employed to evaluate the subject's adjustment to speaking situations and tolerance of stuttering. Both of these self-report techniques rely solely on the accuracy of the subject's report. Analyses of variance were carried out to evaluate the mean difference between groups (less severe and more severe), change-over time (pre-wait, pre-therapy, post-thęrapy, and follow-up), and the differentiated change-over time for the two groups. Results from Gregory's study showed decreases in stuttering between test periods to be significant at the .01 level of confidence for pre-therapy and post-therapy; pre-therapy and follow-up; waiting period and post-therapy; and waiting period and follow-up: Decreases in stuttering were not significant between either waiting period and pre-therapy or post-therapy and follow-up. The mean severity scores for post-therapy and follow-up indicated regression with the mean at follow-up, 3.27 , and the mean at post-therapy, 3.03, although $t$-test comparisons of severity between post-therapy and follow-up were not significant. Findings also indicated reduction of stuttering was greater for the group of more severe stutterers than for the group of 
less severe stutterers. The subject's responses to the two selfreport procedures revealed a decrease in avoidance, more enjoyment of speaking, decreased stuttering, and a better attitude toward stuttering as an outcome of therapy.

In another study Andrews and Inghan (1972a) evaluated and measured the speech of subjects six months prior to treatment, immediately before treatment, immediately after treatment, and at follow-up periods of three, six, and nine months after termination of treatment.

Their study was an evaluation of an intensive twenty-day treatment program of hospitalized stutterers. The program involved the integration of a token economy on two speech modification procedures: syllable timed speech and prolonged speech (Andrews and Ingham, $1972 b)$.

The stuttering behavior of twenty subjects was measured on two principal dimensions, frequency of stuttering and rate of speaking. Andrews and Ingham's (1972a) criterion for fluency was speech with no moments of stuttering, normal nonfluencies, if present, be controllable, and that the rate of conversational speech be within $200 \mp 20$ syllables spoken per minute. The test battery administered to each subject was in two parts, measures of speech behaviors and measures of personality traits. The indices of speech behavior were: 1) percentage of syllables stuttered, 2) individual and group rates of speaking, 3) reaction, avoidance, and severity scales of the Stutterer's SelfRating of Reactions to Speech Situations (Johnson et al., 1963) scale. Aspects of personality were evaluated using three different personality tests. Subjects were seen at three-month intervals for nine 
months following termination of treatment. At each interval the same procedures of evaluation were utilized.

In the six months prior to treatment, performance levels appeared to be relatively unchanged. At the conclusion of treatment, substantial improvement was evident. The three-month review revealed significant relapse. The six- and nine-month results, however, showed movement back toward post-therapy. Because measures of speech performance obtained within the laboratory may provide only one dimension of speech behavior, the reported scores on the self-rating scale and the speech performance measures, as well as the personality test measures, were factor-analyzed. Scores in the laboratory were found to closely parallel the stutterers' assessment of their own speech performances in the outside world.

Two behavioral programs were contrasted in another study in which pre-treatment, post-treatment, and follow-up periods of one, three, and six months were conducted (Perkins, Rudas, Johnson, Michael, and Curlee, 1974):

In Program I, twenty-seven subjects received treatment which emphasized control of rate to maintain fluency. Program II consisted of seventeen subjects who received treatment in which emphasis was placed on control of rate to facilitate normal management of the breathstream, phrasing, and prosody, as well as fluency.

The measurement of stuttering severity for both groups was done in two parts, the number of syllables and syllables spoken per minute were used as the measure of rate. The percentage of syllables stuttered was used as the measure of stuttering. Judgments of fluency, 
rate, and prosody also were rated on a four-point rating scale ranging from normal to abnormal by untrained listeners. Two self-evaluation measures, and three personality tests also were administered.

Results indicated that subjects from both programs showed significant reduction in the percentage of syllables stuttered at the end of treatment and six months after treatment. In Program II 100 percent of the subjects retained their improvements, whereas in Program I only 92 percent showed improvement six months after treatment.

Comparisons of rate and stuttering were made at the end of treatment, and at one, three, and six months after treatment. Rate changed little; the small change that did occur was between one and three months following treatment. The changes in stuttering were sma11 and all occurred within the first three-month post-treatment; no significant change was found between three and six months after treatment. Judgments of normalcy on fluency, rate, and prosody by untrained listeners indicated that they discriminated some of the same differences as did the empirical measures.

In both Programs I and II subjects' responses to self-evaluation scales indicated changes were seen in those areas of performance which were treated and self-evaluations were congruent with differences found in performances.

Prins (1976) conducted a study which was the third in a sequence of studies evaluating the effects of stuttering therapy as perceived by the recipients. The first study (Prins, 1970) provided a questionnaire which ninety-four subjects used to evaluate their improvement and regression across five dimensions of stuttering as described by 
Van Riper (1963). These dimensions were: 1) penalties, 2) frustration, 3) anxiety, guilt, and hostility, 4) communicative stress, and 5) word fears. Results indicated that improvement and regression were not uniform across the stuttering severity dimensions. Speech fluency stood out as showing significantly higher improvement and regression than in any other dimension. Morale showed the least improvement and regression.

In the second study (Prins and Nichols, 1972) the same questionnaire was used to compare the results of the second study with those of the first study. A less intensive six-week nonresidential program was used, and results showed significantly less improvement following therapy. Improvement in fluency was ranked third relative to improvement in other severity dimensions.

In a third study (Prins, 1976) the initial program was replicated with eight children who ranged from mild to very severe stutterers. A modified program also was conducted on nine children who ranged from mild to very severe stutterers. The Riley Stuttering Severity Instrument (SSI) (Riley, 1972) was used to evaluate these subjects.

Samples of spontaneous speech and oral reading were evaluated using the SSI; these results were compared with questionnaire findings. Samples were recorded on video-tape prior to the outset of the program, at the time of the program's completion, and at the follow-up of four and one-half months after termination of the program. The video-tapes were analyzed using the Riley's SSI (1972). Overall stuttering severity scores on this instrument are derived from scales depicting stut- 
tering frequency in percentage of words uttered, duration of the three longest blocks, and the physical concomitants of distracting sounds, facial grimaces, and head and body movements. To assign frequency and duration to an SSI (Riley, 1972) scale value, actual counts of frequency were made from prepared texts, and the duration of the three longest stuttering moments timed with a stopwatch.

Approximately five months following program termination, the children, with assistance from their parents, completed a questionnaire which was identical to the one completed in the earlier studies (Prins, 1970; Prins and Nichols, 1972). This questionnaire was to evaluate their improvement and post-therapy regression in various dimensions of stuttering severity.

Results of the questionnaire revealed that following both programs there was a tendency for high improvement values in a given severity dimension to be followed by high regression. In the initial program, regression values were highest in the area of morale, whereas after the modified program impressions of regression were highest in fluency, even though this was not borne out by the video-tapes.

The video-tapes which were taken, at program termination for the modified program did not reveal a greater degree of speech fluency change to correspond with subject impressions on the questionnaire. Tapes taken at the time of follow-up did show significantly less regression in subjects who participated in the modified program.

The research done by Prins (1970; Prins and Nichols, 1972; Prins, 1976) resembles Van Riper's (1958) series of experiments in stuttering therapy in that in both cases ongoing therapy programs were modified 
along several-dimensions as a consequence of clinical perceptions concerning their strengths and weaknesses.

It is evident from the preceding review of several long-range studies of follow-up that no specific measurement instrument for rating subjects who stutter has been widely accepted and used. Instead, a variety of devices for measuring are employed from selfevaluation scales to panels of judges, and to more specific instruments such as the SSI (Riley, 1972). The decision to measure syllables rather than words per minute as a measure of rate and the percentage of syllables stuttered as the measure of stuttering was used by many studies (Shames, Egolf, and Rhodes, 1969; Andrews and Ingham, 1972a; Curlee and Perkins, 1973; Ryan and Van Kirk, 1.974; Perkins, Rudas, Johnson, Michael, and Curlee, 1974).

Other procedures used in follow-up studies which have been used by more than one study include the use of self-evaluation scales (Gregory, 1972; Andrews and Ingham, 1972a; Perkins, Rudas; Johnson, Michael, and Curlee, 1974) and collecting samples of speech before treatment, at termination of treatment, and at one or more follow-up periods (Prins, 1970; Prins and Nichols, 1972; Prins, 1976). 


\section{CHAPTER III}

METHODS

GENERAL PLAN

Twenty-two subjects who had been placed in an intervention program for stuttering at Portland State University Speech Clinic, from 1972 through 1977, and who were then dismissed or electively terminated from the program, comprised the population of this study.

At arranged times all subjects performed two speaking tasks: a reading task and a job (conversation) task. These speech samples were rated and scored by the examiner at the time of the performances by using the Stuttering Severity Instrument (SSI) (Riley, 1972) (Appendix D). A video-tape was made of the performances to simulate the environment used for baseline testing prior to intervention.

\section{$\underline{\text { Subjects }}$}

A list of potential subjects was determined from the closed speech files, located in the Speech and Hearing Office at Portland State University.

The files of the individuals enrolled in the stuttering program between Fall Term 1972 and Spring Term 1977 were reviewed to determine if the individuals met the following additional criteria:

1) The individual must have been diagnosed as exhibiting stuttering behavior by use of the SSI (Riley, 1972).

2) The individual must have been enrolled in Casteel's Four Stage Stuttering Program. 
3) The individual must have been terminated, either electively or by his or her clinician, from the program during or after completion of Stage III (Decreased Breath), Stage IV (East Talking), or Self-Maintenance.

After reviewing the individual files, forty-eight subjects met the above criteria.

A letter of inquiry (Appendix A) and an information card (Appendix B) were mailed to the most current addresses posted in the files of the forty-eight individuals.

For the individuals whose letters were returned because of incorrect addresses, names were checked in the Portland Metropolitan phone directories to determine if current addresses were listed. Letters were remailed to those with a current address in the telephone directory. If no listing was found for an individual, the telephone information service was called to obtain a telephone number.

Eleven individuals could not be located through the above approach, hence, were eliminated from consideration in the study.

Thirty-seven individuals were contacted by phone and asked the following:

Have you actively participated in any formal program for management of your stuttering (e.g., Webster's program, psychiatry, et cetera) since terminating the program at the Portland State University Speech Clinic?

Two individuals responded "yes" to this question and were asked for further explanation. This clinician then made a judgment in accordance with that explanation (Appendix $C$ ) as to whether the individual was suitable for inclusion in the study. Both had participated in a formal program for their stuttering since terminating the program at Portland State and were not suitable for the study. 
Thirty-five individuals contacted by phone had not participated in any other formal program for their stuttering. These individuals were given an explanation of the purpose of the study, what would be required of them, and then asked to participate in the study.

Two individuals were living out of state and not available for the study. One individual was in the service and the parents of another requested he not participate in the study. Nine individuals did not wish to participate in the study. Twenty-two subjects met all the criteria for inclusion and were willing to participate in the study.

\section{Scheduling Procedure}

The individuals who met criteria and were willing to participate in the study were informed of what they would be asked to do. It was. explained their presence at the Portland State University Speech Clinic would be needed for a twenty to thirty minute appointment, at which time they would be requested to complete a reading and job (conversation) task. An appointment then was made for each individual at the Speech clinic.

There were no other specifications about the appointment time, for the time was dependent on the individual's schedule, the clinician's schedule, and availability of the video-tape equipment.

\section{Instrumentation}

The SSI (Riley, 1972) (Appendix D) was used to score the reading task and the job (conversation) task, and each task was given a frequency score. The frequency scores for the reading and job tasks were 
then added together to obtain a total frequency score. Duration and physical concomitant scores were determined on the basis of both the reading and job tasks. The summation of the frequency, duration, and physical concomitant scores comprised the total SSI score. The range of possible total scores for the SSI ranges from 0 to 45 .

\section{Instrumentation Reliability and Validity}

Riley (1972) standardized the SSI on 109 children and 28 adults. The interexaminer reliability obtained was .84 when a tolerance of plus or minus one STEN was allowed. Frequency and duration were most reliable $(r=.91)$; the physical concomitant measure was less reliable $(r=.62)$.

The validity obtained by Riley (1972) as ranked by the Spearman Rank Correlation Coefficient was computed to be .89 .

Riley (1972) states the statistical reliability and validity appear to qualify the SSI instrument for clinical and research uses, and its validity as measured against other commonly used instrumentation and clinical judgments should be reasonably high.

\section{Nature of the Testing Environment}

The location for the reading and job (conversation) tasks was the Speech and Hearing Sciences Laboratory in the Speech and Hearing Program, Department of Speech Communication of Portland State University. This room was selected because of easy access to the video-tape machine and because the subjects were seen in the laboratory for baseline testing.

During the speaking tasks the examiner was seated next to the 
video-tape machine in order to operate the equipment and still be able to see the subject. The subject stood approximately ten feet from the videotape machine, behind a floor microphone. There were no other furnishings within three feet of the individual, and the video-tape monitor was not viewable by the individual.

\section{Speaking Tasks}

Every subject was given specific, standard instructions by the examiner upon arrival in the speech laboratory:

First, I would like you to read this short passage. You may read it to.yourself first. When you are ready, let me know and I'11 turn on the video-tape and you can read the story out loud.

The reading passage used in this speaking task was "Arthur, the Young Rat" (Johnson, Darley, and Spriesterbach, 1963) (Appendix E). This passage was selected because it is used by the Portland State Stuttering Clinic, it fits the requirements for sufficient number of words according to the SSI, and it is a standardized instrument.

After the subject completed the reading task, he/she was asked to perform a job (conversation) task. The examiner gave the following instructions:

I want you to talk about any topic of your choice.

I would like you to talk for about two minutes. Please keep talking until I signal you to stop. When you are ready, let me know, and I'll turn on the video-tape.

After concluding the taping of the speaking tasks, the examiner played back a small portion of each one to insure that the recording was both auditorially and visually acceptable. 


\section{Scoring Procedure}

In this study, observable physical concomitants were evaluated during the speaking performances, and were scored immediately after the subject had left the room. The frequency and duration parameters were tracked during the speaking performances.

During the speaking tasks every word spoken was represented by a symbol. Words in which there were no disfluencies were represented by a (.). Stuttered instances were represented by a (/) if fleeting, and if judged longer than fleeting; an estimate of duration was tracked instead. In this case in place of a $(/)$ a number was used to indicate duration in seconds. The following is an example of this tracking procedure:

To-Tomorrow is mmmm-my b-birthday. I' 11 bb-be s-sixteen.
(/)
(.)
(2)
(/)
(.)
(1)
(/)

To determine the Total Frequency Score the first twenty-five words were excluded on both the reading and job (conversation) tasks. The percentage of stuttering instances in the next one hundred words in each task was then utilized to give a percentage score. Riley (1972) provided the " $\mathrm{Z}$ " score scale (Appendix D) used for transforming Task Scores. The Task Scores for both the reading and job or conversation tasks were then combined to obtain the Total Frequency Score.

Physical concomitants were defined by Riley (1972) as ". . . the audible and visible phenomena that accompanies the stuttered speech." He grouped all audible distractions into a single category, "distracting sounds," and all visible distractions into three categories, "facial grimaces," "head movement," and "extremities movement." Physical concomitants on stuttered words or with attempts to avoid words 
were scored on Riley's (1972) scale form as: $0=$ none to $5=$ severe (Appendix D).

The physical concomitant area of the SSI was the area most subject to examiner bias. Therefore, the formal rules established in the Master's Thesis by Kimball (1975) were used to assure more reliability in scoring the speech samples in this study (Appendix F).

The Frequency, Duration, and Physical Concomitant scores were then added together and applied to the Portland State University Revised Severity Ratings (Appendix G) to obtain an overal1 severity score. The Portland State University Revised Severity Ratings were designed so as to provide a normalcy range of 0 to 8 , allowing that no individual is 100 percent fluent, since Riley's (1972) Severity Equivalents did not include this range in the severity ratings (Kimbal1, 1975).

Examiner Reliability

Inter- and intrajudge reliability was determined in a pilot study. One judge who had previous training and calibrating in using the SSI (a public school speech pathologist) along with this examiner (a graduate student in speech pathology) evaluated video-tapes of stuttering individuals according to the SSI. The rules for scoring developed by Kimbal1 (1975) were used, in addition to those established by Riley (1972).

In accordance with the Kimball (1975) design for inter- and intrajudge reliability, the scores for each parameter, subparameter, and total performance must be within one point of each other and the total number of words must be in at least 95 percent agreement. This 
examiner and judge were in 99 percent agreement on the job (conversation) task and in 97 percent agreement on the reading task.

\section{Analysis of Data}

The procedures used for statistical treatment of the data were chosen in order to compare the baseline point scores and follow-up point scores as measured by the SSI.

The following statistical methods were used when appropriate: One way F-test analysis of variance; Pearson's product-moment coefficient correlation; and $\underline{t}$-test for differences between means for unrelated and related samples. Significance will be set at the .05 level of confidence. 
CYAPTER IV

RESULTS AND DISCUSSION

RESULTS

The purpose of this study was to conduct a follow-up evaluation of former stuttering clients seen in the Portland State University Stuttering Program, examining maintained fluency in relation to entering baseline scores, time in program, and exit stage. The results of this research are presented in Appendix $G$ and are presented below relative to the major questions posed.

\section{Did the stage in which the client left the program have any}

bearing on the fluency retained?

Twelve of the twenty-two subjects who participated in this study terminated at Stage III, four terminated at Stage IV, and six terminated at the Self-maintenance level (Table I).

A one way analysis of variance of the twenty-two subjects as a group resulted in an $F$ value of 1.40 . To be significant at the .05 level of confidence an $F$ value of 3.52 was needed, d.f. $(2,19)$. The $F$ value was not significant at the .05 level of confidence (Table II).

A t-test for differences between means, for unrelated samples was computed on the subjects who terminated at Stage III and Stage IV. The $t$ value was 0.14 ; to be significant at the .05 level of confidence the $\underline{t}$.value needed to be 2.15 , d.f. 14. The $\underline{t}$ value for subjects who 
TABLE I

PROGRAM STAGE AT TERMINATION

AND SEVERITY SCORES

\begin{tabular}{|c|c|c|c|}
\hline Stage & Subject & $\begin{array}{c}\text { Baseline } \\
\text { Severity } \\
\text { Score }\end{array}$ & $\begin{array}{c}\text { Follow-up } \\
\text { Severity } \\
\text { Score }\end{array}$ \\
\hline \multirow{12}{*}{ Stage III } & A & 13 & 5 \\
\hline & B & 19 & 13 \\
\hline & $\mathrm{F}$ & 27 & 10 \\
\hline & G & 16 & 16 \\
\hline & $\mathrm{H}$ & 14 & 1 \\
\hline & $\mathrm{I}$ & 14 & 3 \\
\hline & $\mathrm{J}$ & 38 & 26 \\
\hline & M & 12 & 10 \\
\hline & $\mathrm{N}$ & 9 & 0 \\
\hline & $\mathrm{P}$ & 11 & 1 \\
\hline & $Q$ & 26 & 3 \\
\hline & $\mathrm{S}$ & 28 & 0 \\
\hline \multirow{4}{*}{ Stage IV } & $\mathrm{C}$ & 19 & 7 \\
\hline & $\mathrm{D}$ & 22 & 19 \\
\hline & $\mathrm{E}$ & 7 & 0 \\
\hline & $\mathrm{R}$ & 6 & 6 \\
\hline \multirow{6}{*}{ Self-Maintenance } & K & 29 & 11 \\
\hline & L & 22 & 8 \\
\hline & 0 & 16 & 3 \\
\hline & $\mathrm{T}$ & 19 & 7 \\
\hline & $\mathrm{U}$ & 31 & 37 \\
\hline & V & 24 & 25 \\
\hline
\end{tabular}

terminated at Stage III and Stage IV was not significant at the .05 level of confidence (Table III).

A $t$-test for differences between means, for unrelated samples was computed on subjects who terminated at Stage III and SelfMaintenance. The $t$ value was 1.59 ; to be significant at the .05 level of confidence the $t$ value needed to be 2.12 , d.f. 16 . The $\underline{t}$ value for subjects who terminated at Stage III and Self-Maintenance was not 
TABLE II

F-TEST ANALYSIS OF VARIANCE FOR

TERMINATION STAGES

\begin{tabular}{lccccc}
\hline \hline Source & df & Sums of Squares & Mean Square \\
\hline Between & 2 & $2.578181818 \mathrm{E}$ & 02 & $1.289090909 \mathrm{E}$ & 02 \\
Error & 19 & $1.747500000 \mathrm{E}$ & 03 & $9.197368421 \mathrm{E}$ & 01 \\
Tota1 & 21 & $2.005318182 \mathrm{E}$ & 03 & & \\
\hline
\end{tabular}

$F=1.40$

$\mathrm{F}_{.05}(2,19)=3.52$

TABLE III

t-TEST FOR DIFFERENCES BETWEEN MEANS FOR TERMINATION STAGES

\begin{tabular}{|c|c|c|c|}
\hline Stage & $\begin{array}{l}\frac{t-t e s t}{V} \text { alue } \\
\text { tus }\end{array}$ & $\mathrm{df}$ & $\begin{array}{c}.05 \text { Leve } 1 \\
\text { of } \\
\text { Confidence }\end{array}$ \\
\hline III and IV & $.14 \%$ & 14 & 2.15 \\
\hline $\begin{array}{l}\text { III and Self- } \\
\text { Maintenance }\end{array}$ & $1.58 \%$ & 16 & 2.12 \\
\hline $\begin{array}{l}\text { III, IV , and } \\
\text { Self-Maintenance }\end{array}$ & $.97 \%$ & 8 & 2.30 \\
\hline
\end{tabular}


significant at the .05 level of confidence (Table III).

A t-test for differences between means, for unrelated samples computed on subjects who terminated at Stage IV and Self-Maintenance resulted in a $\underline{t}$ value of .97 ; to be significant at the .05 level of confidence the $\underline{t}$ value needed to be 2.30 , d.f. 8 . The $\underline{t}$ value for subjects who terminated at Stage IV and Self-Maintenance was not significant at the .05 level of confidence (Table III).

Did the number of terms of clinic a client received have any bearing on fluency retained?

The length of intervention of the twenty-two subjects who participated in this study ranged from one to six terms. One subject was seen for only one term, eight subjects two terms, eight subjects three terms, four subjects five terms, and one subject for six terms (Table IV).

A one way analysis of variance was computed on the subjects as a group. The $F$ value was .43 ; to be significant at the .05 level of confidence an $F$ value of 3.59 was needed, d.f. $(2,17)$. The $F$ value was not significant at .05 level of confidence (Table V).

A $\underline{t}$-test for difference between means, for unrelated samples was computed on subjects seen for two and three terms of clinic. The $\underline{t}$ value was .10 ; to be significant at the .05 level of confidence the $t$ value needed to be 2.15 , d.f. 14. The $\underline{t}$ value for subjects seen two and three terms was not significant at the .05 level of confidence (Table VI).

A t-test for difference between means, for unrelated samples was computed on subjects seen for two and five terms of clinic. The $\underline{t}$ 
TABLE IV

TERMS IN MANAGEMENT AND

SEVERITY SCORES

\begin{tabular}{|c|c|c|c|}
\hline $\begin{array}{l}\text { Terms in } \\
\text { Management }\end{array}$ & Subject & $\begin{array}{l}\text { Baseline } \\
\text { Severity } \\
\text { Score }\end{array}$ & $\begin{array}{l}\text { Follow-up } \\
\text { Severity } \\
\text { Score }\end{array}$ \\
\hline 1 Term & A & 13 & 5 \\
\hline \multirow{8}{*}{2 Terms } & B & 19 & 13 \\
\hline & $\mathrm{C}$ & 19 & 7 \\
\hline & D & 22 & 19 \\
\hline & $\mathrm{E}$ & 7 & 0 \\
\hline & F & 27 & 10 \\
\hline & G & 16 & 16 \\
\hline & $\mathrm{H}$ & 14 & 1 \\
\hline & I & 14 & 3 \\
\hline \multirow{8}{*}{3 Terms } & $\mathrm{J}$ & 38 & 26 \\
\hline & $\mathrm{K}$ & 29 & 11 \\
\hline & $\mathrm{L}$ & 22 & 8 \\
\hline & M & 12 & 10 \\
\hline & $\mathrm{N}$ & 9 & 0 \\
\hline & 0 & 16 & 3 \\
\hline & $\mathrm{P}$ & 11 & 1 \\
\hline & Q & 26 & 3 \\
\hline \multirow{4}{*}{5 Terms } & $S$ & 28 & 0 \\
\hline & $\mathrm{T}$ & 19 & 7 \\
\hline & $\mathrm{R}$ & 6 & 6 \\
\hline & $\mathrm{U}$ & 31 & 37 \\
\hline 6 Terms & V & 24 & 25 \\
\hline
\end{tabular}

value was .81 ; to be significant at the .05 level of confidence the $t$ value needed to be $2.23, \mathrm{~d} . \mathrm{f} .10$. The $t$ value for subjects seen two and five terms was not significant at the .05 level of confidence (Table VI).

A $t$-test for differences between means, for unrelated samples was computed on subjects seen for three and five terms of clinic. The 
TABLE $\mathrm{V}$

F-TEST ANALYSIS OF VARIANCE FOR

TERMS IN MANAGEMENT

\begin{tabular}{lrrrrr}
\hline \hline Source & df & Sums of Squares & Mean Square \\
\hline Between & 2 & $7.857500002 \mathrm{E}$ & 01 & $3.928750001 \mathrm{E}$ & 01 \\
Error & 17 & $1.558375000 \mathrm{E}$ & 03 & $9.166911764 \mathrm{E}$ & 01 \\
Tota1 & 19 & $1.636950000 \mathrm{E}$ & 03 & \\
\hline & $\mathrm{F}=$ & .43 & & & \\
$\mathrm{~F} .05$ & $(2,17)=3.59$
\end{tabular}

TABLE VI

t-TEST FOR DIFFERENCES BETWEEN MEANS

FOR TERMS IN MANAGEMENT

\begin{tabular}{lccc}
\hline & & .05 Level \\
$\begin{array}{c}\text { Terms of } \\
\text { Clinic }\end{array}$ & $\begin{array}{c}\text { t-test } \\
\text { Value }\end{array}$ & df & Confidence \\
\hline $2 \& 3$ Terms & $.10 *$ & 14 & 2.15 \\
$2 \& 5$ Terms & $.81 *$ & 10 & 2.23 \\
$3 \& 5$ Terms & $.67 *$ & 10 & 2.23 \\
\hline \\
$* \mathrm{P}\rangle .05$
\end{tabular}


$t$ value was .67 ; to be significant at the .05 level of confidence the $\underline{t}$ value needed to be 2.23 , d.f. 10 . The $t$ value for subjects seen three and five terms was not significant at the .05 level of confidence (Table VI).

Did the length of time elapsed since the client terminated the program have any bearing on fluency retained?

The time elapsed since the twenty-two subjects were terminated from intervention ranged from one to five years. In Table VII it may be seen six subjects had not been seen for one year, seven for tivo years, three for three years, four for four years, and two for five years.

A Pearson's product-moment coefficient correlation was computed for the subjects' follow-up scores and time elapsed since termination. The correlation was . 12 ; this is a very low correlation and is not significant.

What relationship exists between baseline and follow-up scores?

Eighteen of the twenty-two subjects who participated in this study demonstrated severity scores at follow-up lower than their baseline scores. Of. the four subjects who did not demonstrate severity scores at follow-up lower than their baseline scores, two subjects received identical scores for baseline and follow-up and two subjects received higher scores at follow-up (Table VIII).

A $\underline{t}$-test for difference between means, for related samples was computed on baseline and follow-up scores. The $\underline{t}$ value was 3.50 ; to be significant at the .05 level of confidence the $\underline{t}$ value needed to be 
TABLE VII

TIME ELAPSED SINCE TERMINATION

AND SEVERITY SCORES

\begin{tabular}{|c|c|c|c|}
\hline $\begin{array}{l}\text { Years Since } \\
\text { Termination }\end{array}$ & Subject & $\begin{array}{l}\text { Baseline } \\
\text { Severity } \\
\text { Score }\end{array}$ & $\begin{array}{l}\text { Follow-up } \\
\text { Severity } \\
\text { Score }\end{array}$ \\
\hline 1 Year & $\begin{array}{l}C \\
D \\
F \\
P \\
S \\
U\end{array}$ & $\begin{array}{l}19 \\
22 \\
27 \\
11 \\
28 \\
31\end{array}$ & $\begin{array}{r}7 \\
19 \\
10 \\
1 \\
0 \\
37\end{array}$ \\
\hline 2 Years & $\begin{array}{l}\mathrm{H} \\
\mathrm{L} \\
\mathrm{M} \\
\mathrm{N} \\
\mathrm{O} \\
\mathrm{Q} \\
\mathrm{R}\end{array}$ & $\begin{array}{r}14 \\
22 \\
12 \\
9 \\
16 \\
26 \\
66\end{array}$ & $\begin{array}{r}1 \\
8 \\
10 \\
0 \\
3 \\
3 \\
6\end{array}$ \\
\hline 3 Years & $\begin{array}{l}\mathrm{B} \\
\mathrm{T} \\
\mathrm{A}\end{array}$ & $\begin{array}{l}19 \\
19 \\
13\end{array}$ & $\begin{array}{r}13 \\
7 \\
5\end{array}$ \\
\hline 4 Years & $\begin{array}{l}\text { I } \\
\text { K } \\
\text { G } \\
\text { V }\end{array}$ & $\begin{array}{l}14 \\
29 \\
16 \\
24\end{array}$ & $\begin{array}{r}3 \\
11 \\
16 \\
25\end{array}$ \\
\hline 5 Years & $\begin{array}{l}\mathrm{E} \\
\mathrm{J}\end{array}$ & $\begin{array}{r}7 \\
38\end{array}$ & $\begin{array}{r}0 \\
26\end{array}$ \\
\hline
\end{tabular}

2.02, d.f. 42. The $\underline{t}$ value for baseline and follow-up scores was significant at the .05 level of confidence (Table IX).

A Pearson's product-moment coefficient correlation was computed for baseline and follow-up scores. The correlation was .61, which is a moderate correlation and substantial relationship. 
TABLE VIII

VARIATION IN SEVERITY SCORES BETWEEN

BASELINE AND FOLLOW-UP

\begin{tabular}{|c|c|c|c|}
\hline Follow-up Score & Subject & $\begin{array}{l}\text { Baseline } \\
\text { Severity } \\
\text { Score }\end{array}$ & $\begin{array}{c}\text { Follow-up } \\
\text { Severity } \\
\text { Score }\end{array}$ \\
\hline \multirow{18}{*}{$81.8 \%$ Lower } & A & 13 & 5 \\
\hline & B & 19 & 13 \\
\hline & $\mathrm{C}$ & 19 & 7 \\
\hline & $\mathrm{D}$ & 22 & 19 \\
\hline & $E$ & 7 & 0 \\
\hline & $\mathrm{F}$ & 27 & 10 \\
\hline & $\mathrm{H}$ & 14 & 1 \\
\hline & $I$ & 14 & 3 \\
\hline & $\mathrm{J}$ & 38 & 26 \\
\hline & $\mathrm{K}$ & 29 & 11 \\
\hline & $\mathrm{L}$ & 22 & 8 \\
\hline & $M$ & 12 & 10 \\
\hline & $\mathrm{N}$ & 9 & \multirow{6}{*}{$\begin{array}{l}0 \\
3 \\
1 \\
3 \\
0 \\
7\end{array}$} \\
\hline & 0 & 16 & \\
\hline & $\mathrm{P}$ & 11 & \\
\hline & $Q$ & 26 & \\
\hline & S & 28 & \\
\hline & $\mathrm{T}$ & 19 & \\
\hline & $\mathrm{R}$ & 6 & 6 \\
\hline $9.1 \%$ Identical & $G$ & 16 & 16 \\
\hline \multirow{2}{*}{$9.1 \%$ Higher } & $\mathrm{U}$ & 31 & 37 \\
\hline & $\mathrm{V}$ & 24 & 25 \\
\hline
\end{tabular}

What percentage of the subjects maintained fluency improvement within the established normal limits of 0 to 8 on the stuttering

Severity Instrument scale?

An examination of Table $X$ reveals thirteen of the twenty-two subjects ( 59.1 percent) demonstrated normal category ratings at follow-up. Eleven of the thirteen subjects $\left(50.0^{\circ}\right.$ percent) demonstrated 
TABLE IX
t-TEST FOR DIFFERENCES BETWEEN MEANS FOR
BASELINE AND FOLLOW-UP
SEVERITY SCORES

\begin{tabular}{|c|c|c|c|}
\hline Score & $\begin{array}{l}\text { t-test } \\
\text { Value }\end{array}$ & $d f$ & $\begin{array}{c}.05 \text { Leve } 1 \\
\text { of } \\
\text { Confidence }\end{array}$ \\
\hline $\begin{array}{l}\text { Baseline \& } \\
\text { Follow-up }\end{array}$ & $3.50 \mathrm{kr}$ & 42 & 2.02 \\
\hline
\end{tabular}

movement from baseline severity categories to the normal category at follow-up. Two of the thirteen subjects demonstrated normal category ratings for both baseline and follow-up. The percentage of individuals who demonstrated normal baseline and follow-up categories was 9.1 percent (Table X).

\section{DISCUSSION}

In consideration of the data presented in the previous section, interpretation of the findings was made. Discussion of these findings is presented below relative to the question posed.

Did the stage in which the client left the program have any bearing on fluency retained?

Comparison of fluency scores between Stage III and Stage IV, Stage III and Self-Maintenance, and Stage IV and Self-Maintenance indicates termination in one stage rather than in another was not sig- 
TABLE X

COMPARISONS OF NORMAL RATINGS AT FOLLOW-UP AND

SEVERITY RATINGS AT BASELINE

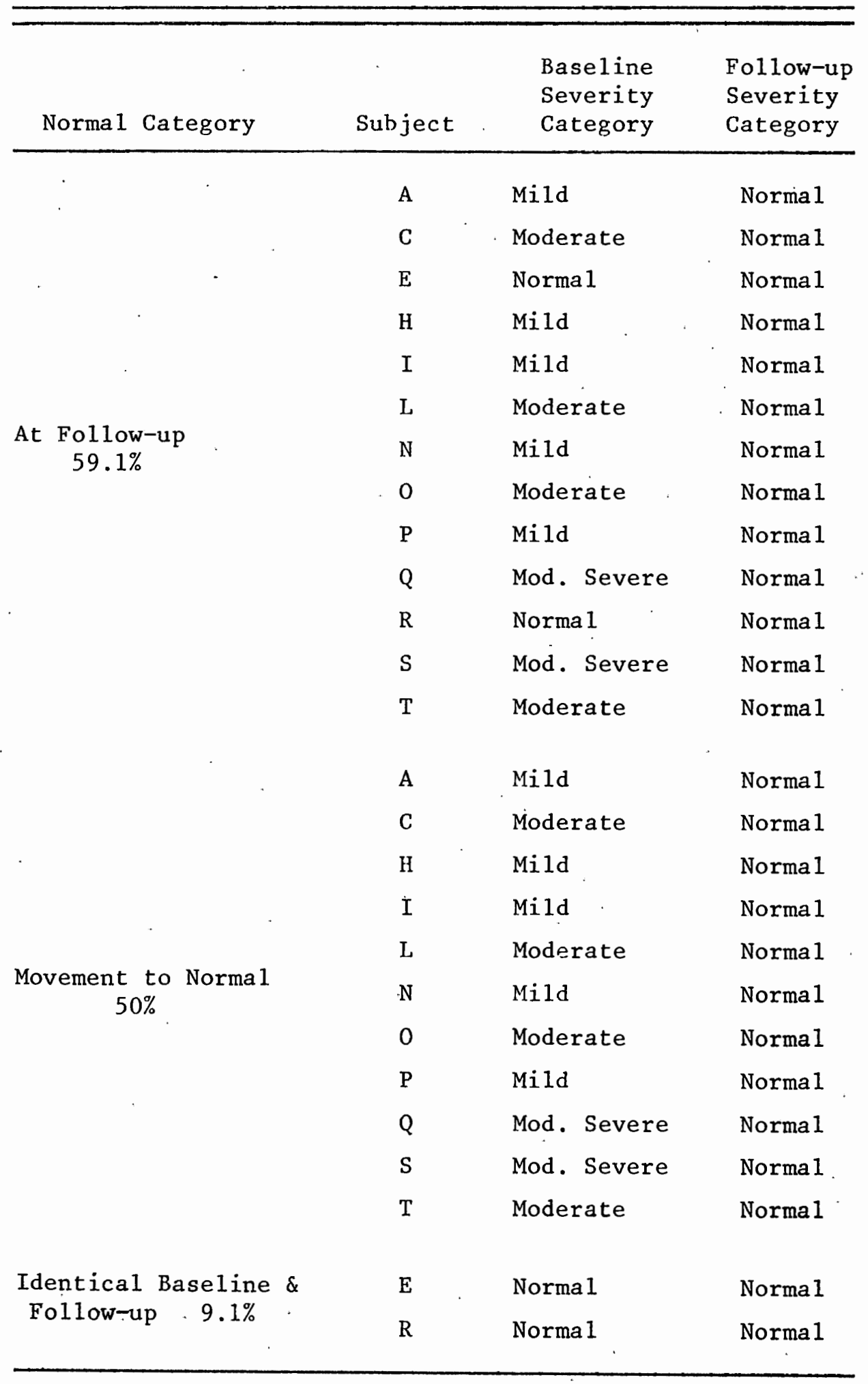


nificant to fluency retained at follow-up. It appears individuals terminating in Stage III retained fluency at follow-up, as well as those terminating in Stage IV or during Self-Maintenance, and individ. uals terminating in Self-Maintenance did not retain fluency any better than individuals in Stage III or IV.

It would seem that by Stage III some individuals have learned what they need to do to talk fluently. The possibility that Stage IV and Self-Maintenance are not essential for the individual to complete in order to obtain fluency raises the question as to why some individuals need to complete Stage IV and Self-Maintenance. One reason may be the clinician working with the individual feels he needs more time in clinic to refine his skill for talking fluently. Another possible reason may be the individual feels insecure about his abilities and continues either in Stage IV and/or into Self-Maintenance in order to refine his skills, or to get a sense of closure through competition of the whole program.

Did the number of terms of clinic a client received have any bearing on fluency retained?

Comparison of fluency scores for individuals seen for two and three terms, two and five terms, and three and five terms indicated the number of terms of clinic were not significant in fluency retained. This would tend to indicate individuals seen for two terms did as well at retaining fluency as individuals seen three or five terms, and individuals seen for five terms did not retain fluency any better than those individuals seen for two and three terms. When the majority of individuals terminated after two or three 
terms of clinic, the question as to why some individuals continue longer in clinic arises. Possibly the individuals who continue after three terms of clinic are insecure about their abilities to talk fluently and seek more clinic to overcome their insecurities. Another reason may be their fluency is more fragile and the clinician working with them feels they need more time in clinic. It also is possible those individuals who continue in clinic have developed some dependence on the program or their clinician, and have not taken responsibility for their fluency. Also, the length of time to complete Stages I and II is a factor to consider when looking at the number of terms an individual spent in clinic. The length of time in Stages I and II varies from individual to individual and thus the total time spent in clinic would vary a1so. An individual's attendance also may contribute to the number of terms an individual spends in clinic. Poor attendance may increase the time spent by an individual in clinic since this individual would need to attend clinic over a longer period of time to 'cover the same information an individual who attended regularly covered.

Did the length of time elapsed since the client terminated the program have any bearing on fluency retained?

The correlation of .12 between baseline and follow-up scores indicates the length of time elapsed between termination and follow-up was not significant to fluency retained.

Since the length of time elapsed since termination is not significant, it might be concluded different clinicians using this program did not influence the individual's fluency retention over time. 
Minor program modifications made during the past five years also would not appear to influence the retention of fluency over time.

What relationship: exists between baseline and follow-up scores?

A moderately significant relationship was found between baseline and follow-up scores. This would suggest that the severity at baseline would have significant relation to the severity demonstrated at followup. Therefore, if the severity at baseline was found to be high; it is more likely the follow-up severity might be high. A correlation between baseline and follow-up scores substantiated a significant relationship, but it must be remembered it was not a high correlation and every individual with a high baseline severity will not receive a high follow-up severity. This was demonstrated by subject $S$ who received a baseline score of 25 (moderately severe severity) and a follow-up score of 0 (normal fluency) (Appendix H).

A possible reason for the relationship between baseline and follow-up severity may be individuals who are more severe have experienced more failures and have a greater variety of situations in which negative stimulus for fluency are present. Individuals who are severe will have more situations in which they must cope than the individual who is less severe, and thus the severe client could experience greater difficulty in maintaining fluency.

What percentage of the subjects maintained fluency improvement within the established normal limits of 0 to 8 on the Stuttering Severity Instrument scale?

Seven of the twenty-two subjects demonstrated moderately severe 
or severe severity ratings at baseline. Even as Iong as five years after termination five subjects demonstrated a severity rating at follow-up at least two severity categories lower. One subject demonstrated a higher severity category at follow-up, and one subject demonstrated an identical severity rating for baseline and follow-up.

All of the seven subjects who demonstrated moderate severe or severe severity at baseline had more than one term of clinic, only one had two terms, and the majority had three to six terms.

The subcategories on the SSI (Riley, 1972) for fluency, duration, and concomitant behaviors revealed that of these seven subjects who were moderately severe or severe at baseline three received lower scores in all three subcategories at follow-up. Two subjects received identical frequency and duration scores but higher concomitant behavior scores at follow-up. One subject received lower frequency and duration scores but a higher concomitant behavior score. Baseline subcategory scores were not available for one subject.

The three subjects who received higher concomitant behavior scores were not seen for consecutive terms of clinic; time lapses of at least one year occurred between their terms in clinic. Two of these subjects received five to six terms of clinic.

Ten of the fifteen subjects who demonstrated moderate to normal severity ratings at baseline demonstrated severity at follow-up at least one category lower. Two of the five subjects who did not demonstrate lower severity category ratings at follow-up received normal severity ratings at baseline and follow-up. The other three subjects who did not demonstrate lower severity category ratings at follow-up 
received identical baseline and follow-up severity ratings.

Two of the fifteen subjects who demonstrated moderate to normal severity ratings at baseline received five terms of clinic, one received one term, and the majority received two to three terms. It is interesting that one of the subjects who received five terms of clinic demonstrated a severity rating of normal for both baseline and follow-up. It is possible this individual was insecure about his speech and considered himself a stutterer and continued in the program for five terms to overcome his insecurities. The other subject who received five terms of clinic was an adolescent when participating in the program, and it is possible he was continued for five terms to insure he took responsibility for his speech.

The subcategories of the SSI for fluency, duration, and concomitant behaviors indicated that for the fifteen subjects who demonstrated moderate to normal severity ratings at baseline, thirteen received lower frequency scores, twelve received lower scores in duration, and eleven received lower concomitant scores. Subcategory scores were not available for one individual. Thus, it appears these individuals for the most part improved in at least one aspect of stuttering behavior, fluency, duration, or concomitant behaviors, whether they improved in overall score or not. 
CHAPTER V

SUMMARY AND IMPLICATIONS

SUMMARY

The use of so many different therapeutic approaches to stuttering raises frequent questions about methodology and treatment. Confidence in a methodology and treatment approach depends upon follow-up research conducted with systematic analysis of the individuals prior to treatment and following treatment.

The purpose of this study was to conduct a follow-up evaluation on R. L. Casteel's Four Stage Stuttering Program at Portland State University and to examine the degree of maintained fluency in relation to entering baseline, time in program, and exit stage.

Twenty-two subjects were seen who had terminated the program in Stage III, Stage IV, or Self-Maintenance. The length of time elapsed since these subjects terminated from clinic ranged from one to five years. They had received one to six terms of clinic.

The results of this research indicate approximately 50 percent success rate with Casteel's Four Stage Stuttering Program. The length of time in clinic and the length of time elapsed since termination were not significant factors in fluency retained at follow-up. Also the stage (Stage III, Stage IV, or Self-Maintenance) in which an individual terminated the program was not significant to fluency retained at follow-up. The research does indicate a significant 
relationship between severity at baseline and severity at follow-up, indicating a client with a higher severity at baseline may have a higher severity at follow-up.

The percentage of the twenty-two individuals who participated in this study and demonstrated improvement in point scores was 81.8 percent. The percentage of individuals who demonstrated movement to a lower severity category was 68.1 percent. The percentage of subjects who demonstrated normal fluency at follow-up was 59.1 percent, with 50 percent of the subjects demonstrating movement to normal fluency from a higher level of severity. The results indicate 68.1 percent of the twenty-two subjects who participated in this study had acquired some lasting skill in knowing what to do to be fluent.

\section{IMPLICATIONS}

\section{Clinica1}

The research from this study indicates about 50 percent success rate with Casteel's Four Stage Stuttering Program. Although we do not know what these individuals do in other situations, 59.1 percent demonstrate skill in knowing what to do to talk fluently at follow-up. Clinically, from the research we know Stage III individuals retain fluency, as well as Stage IV and Self-Maintenance individuals. We can assume the skills necessary to be fluent are taught before the individual leaves Stage III. So whatever the individual obtains clinically in the first three stages is very important therapeutically.

We wonder if the length of time an individual takes to acquire Stages I and II might be more significant than the exit time from the 
program.

\section{Research}

The implications of this research on future research are many. The research done for this study was the initial groundwork research. Through this research contact with former clients was established and records updated for address and phone numbers. A need for formal consistent reporting of pre- and post-testing results was identified.

Continued research on clients who terminate from the stuttering program is needed to provide progress on the program's results. Eventually, follow-up research to compare baseline severity, terminating severity, and follow-up severity to determine regression at follow-up is needed.

Other possible expansions on this research include comparing the individuals who did not participate in this study with those who did. The individuals who participated might be examined by questionnaire to determine their impressions about and effectiveness of the program. Most of all, for reliability and validity an examiner trained in the SSI for research purposes might compare the video-tape from this research with the original baseline video-tapes of the same individuals. 


\section{SELECTED BIBLIOGRAPHY}

ANDREWS, G., and INGHAM, R. J., Stuttering: Considerations in the evaluation of treatment. British J. of Dis. Comm., 6, 129-137 (1971).

ANDREWS, G., and INGHAM, R. J., An approach to the evaluation of stuttering therapy. J. Speech Hearing Res., 15, 296-302 (1972a).

ANDREWS, G., and INGHAM, R. J., Stuttering: An evaluation of followup procedures for syllable-timed speech/token system therapy. J. of Comm. Dis., 5, 307-319 (1972b).

BLOODSTEIN, 0.,. Development of stuttering: Theoretical and clinical implications. J. Speech Hearing Dis., 26, 67-82 (1961).

CASTEEL, R. L., Modification of stuttering through a series of discrimination tasks. Paper presented at the ASHA Western Regional Conference, Portland, Oregon, 28 May 1976.

CASTEEL, R. L., and MCMAHON, J., Modification of stuttering in a public school setting. J. of Childhood Com. Dis., 2, 6-17 (1978).

CHERRY, E. C., and SAYERS, B., Experiments upon total inhibition of stammering by external control, and some clinical results. J. Psychosom. Res., 1, 233-346 (1956).

COOPER, E. B., Recovery from stuttering in a junior and senior high school population. J. Speech Hearing Res., 15, 632-638 (1972).

CURLEE, R. F :, and PERKINS, W. H., Effectiveness of a DAF conditioning program for adolescent and adult stutterers. Behavior Res. and Therapy, 11, 395-401 (1973).

FRANSELLA, F., and BEECH, H., An experimental analysis of the effect of rhythm on the speech of stutterers. Behavior Res. and Therapy, 3, 195-201 (1965).

GREGORY, H. H:, An assessment of the results of stuttering therapy. J. of Comm. Dis., 5, 320-334 (1972).

INGHAM, R. J., A comparison of covert and overt assessment procedures in stuttering therapy outcome evaluation. J. Speech Hearing Res., $18,346-354$ (1975).

INGHAM, R. J., and ANDREWS, G., Stuttering: Quality of fluency after treatment. J. of Comm. Dis., 4, 279-288 (1971). 
INGHAM, R. J., and ANDREWS, G., Behavior therapy and stuttering: A review. J. Speech Hearing Dis., 38, 405-422 (1973).

JOHNSON, W., DARLEY, F. L., and SPRIESTERBACH, D., Diagnostic Methods in Speech Pathology. New York: Harper and Row (1963).

KIMBALL, C. D., Recovery from stuttering in a sample of elementary school children. Master thesis, Portland State University (1975).

PERKINS, W. H., RUDAS, J., JOHNSON, L., MICHAEL, W. B., and CURLEE, R. F., Replacement of stuttering with normal speech: III Clinical effectiveness. J. Speech Hearing Dis., 39, 416-427 (1974):

PRINS, D., Improvement and regression in stutterers following shortterm intensive therapy. J. Speech Hearing Dis., 35, 123-134 (1970).

PRINS, D., Stutterers's perceptions of therapy improvement and of post-therapy regression: Effects of certain program modifications. J. Speech Hearing Dis., 14, 452-563 (1976).

PRINS, D., and NICHOLS, A., Client impressions of the effectiveness of stuttering therapy: A comparison of two programs. British J. of Dis. Comm., 9, 123-133 (1972).

RILEY, G. D., A stuttering severity instrument for children and adults. J. Speech Hearing Dis., 37, 314-321 (1972).

RYAN, B. P., and VAN KIRK, B., Establishment, transfer, and maintenance of fluent speech in 50 stutterers using delayed auditory feedback and operant procedures. J. Speech Hearing Res., 39, 3-10 (1974).

SHAMES, G. H., EGOLF, D. B., and RHODES, R. C., Experimental programs in stuttering therapy. J: Speech Hearing Dis., 34, 30-47 (1969).

SHEEHAN, J. G., and MARTYN, M. M., Spontaneous recovery from stuttering. J. Speech Hearing Res., 9, 121-135 (1966).

SHEEHAN, J. G., and VOAS, R. B., Stuttering as conflict: Comparisons of therapy techniques involving approach and avoidance. $\mathrm{J}$. Speech Hearing Dis., 22, 714-723 (1957).

VAN RIPER, C., Experiments in stuttering therapy. In J. Eisenson (Ed.), Stuttering: A Symposium. New York: Harper and Row (1958).

VAN RIPER, C., Speech Correction: Principles and Methods. Englewood Cliffs, N. J.: Prentice Hall (1963).

WINGATE, M. E., Recovery from stuttering. J. Speech Hearing Dis., 29, 312-321 (1964). 
WINGATE, M. E., Fear of stuttering. ASHA, 3, 3-5 (1971). 
APPENDIX A

LETTER OF INQUIRY

March 10, 1978

\title{
NAME
}

ADDRESS

CITY, STATE

Dear NAME:

I am a graduate student in the Speech Department of Portland state University, and I am currently developing my Master's Thesis in Speech Pathology.

My research includes examining the speech of past stuttering clients (twenty to thirty minutes) who have attended the Portland State University Stuttering Clinic.

Before beginning my study, I need to contact past stuttering clients in order to determine individuals who are willing to participate in my study.

I would appreciate your completing the enclosed note card and returning it as soon as possible in the enclosed envelope. Returning this card does not commit you to participate in this study, but it will give me the information to contact you further for explanation of my study. If you should wish not to be contacted further about this matter, please indicate on the note card in the appropriate space.

I appreciate your assistance.

\author{
Sincerely, \\ Priscilla Ginter \\ R. L. Casteel \\ Clinical Supervisor
}

Enc. 
APPENDIX B

INFORMATION CARD

Name

Address

The most convenient hours at which I can be reached:

$\begin{array}{lll}\text { Monday_ } & \text { Tuesday_ } & \text { Wednesday } \\ \text { Thursday_ } & \text { Friday } & \text { Saturday } \\ \text { Sunday } & \text { I do not wish to participate }\end{array}$

The phone number at which I can be reached is 
APPENDIX C

CLASSIFICATION OF OTHER PROGRAMS*

Suitable for study:

1) Attended a group, such as the Stuttering Council but did not actively participate in a formal stuttering program.

2) Were seen by a psychologist or psychiatrist for other reasons and stuttering was brought out and dealt with.

3) Gone for evaluation of stuttering behavior but were not seen formally by clinician on a regular basis.

Unsuitable for study:

1) Participated in a formal stuttering program where they were seen by a clinician on a regular basis.

2) Currently receiving services dealing with their stuttering behavior.

3) Have met in a group setting whose purpose was intervention for stuttering.

*Explanations which did not fall into one of these areas for classification were discussed with thesis director for final decision. 


\section{APPENDIX D \\ STUTTERING SEVERITY INSTRUMENT \\ EVALUATION SCALE \\ (Riley, 1972)}

Frequeney (Use A or B. not both)

\begin{tabular}{|c|c|c|c|c|c|}
\hline \multicolumn{4}{|c|}{ A. For readers. Use $I$ and 2.} & \multirow{2}{*}{\multicolumn{2}{|c|}{$\begin{array}{l}\text { D. For nonreaders } \\
\text { Picture Tash }\end{array}$}} \\
\hline \multicolumn{2}{|c|}{ 1. Job Task } & \multicolumn{2}{|c|}{ 2. Reading Task } & & \\
\hline $\begin{array}{l}\text { Per. } \\
\text { remloge }\end{array}$ & $\begin{array}{l}\text { Task } \\
\text { Score }\end{array}$ & $\begin{array}{l}\text { Per. } \\
\text { cenlage }\end{array}$ & $\begin{array}{l}\text { Tash } \\
\text { Score }\end{array}$ & $\begin{array}{c}\text { Per. } \\
\text { centoge }\end{array}$ & $\begin{array}{l}\text { Tosh } \\
\text { Score }\end{array}$ \\
\hline $\mathbf{I}$ & 2 & 1 & 2 & 1 & 1 \\
\hline 3.9 & 3 & $2-3$ & 2 & $2-3$ & 6 \\
\hline 4 & 4 & 45 & 5 & 1 & 8 \\
\hline $5-6$ & 5 & $6-9$ & 6 & $5-6$ & 10 \\
\hline $7-9$ & 6 & $10-16$ & 7 & $7-9$ & 12 \\
\hline $10-14$ & 7 & $17-26$ & B & $10-14$ & 14 \\
\hline $19-28$ & 8 & 27 and up & 9 & $15-28$ & 16 \\
\hline
\end{tabular}

Tolal
Firequency
Scorc
1 1 \&
or

\section{Buration}

\begin{tabular}{|c|c|}
\hline Estimnted l.ength of Three Longest Blochs & Taik Scare \\
\hline $\begin{array}{l}\text { Feeting } \\
\text { One hall xecond } \\
\text { One full second } \\
2 \text { to } 9 \text { xeconds } \\
10 \text { to } 30 \text { second, (by recond hand) } \\
30 \text { to } 60 \text { seconds } \\
\text { More than } 60 \text { seconda }\end{array}$ & $\begin{array}{l}1 \\
2 \\
3 \\
4 \\
5 \\
6 \\
7\end{array}$ \\
\hline
\end{tabular}

Total Duration Score

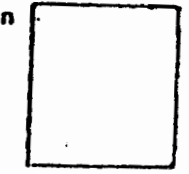

\section{Phyoical Concomliants}

F.valuating Scale: $0=$ none; $1=$ not noticcible unless looking lor 11: 2 - barely noticeable to casual observer: 3 a distracting: $1=$ very distracting: 5 exvere and painful looking.

1. Distracting Sounds. Noisy breathing. whistling. sniffng. blowing. clicking wounde........... $0123+5$

2. Facial grimaces. Jaw jerking, congue protruding. lip presing. jaw muscles cenue.............

3 llesd movement. Buck. Lorward. turning away. pert eye contuct. constant looking around...... 012345

1 Pexemitier movement. Arm and hand move. ment, hand, aboul face. torso movement. Ieg roovements. lool tapping or swinging......... 0 I 2345

Tolal Physical Concotoriant Score 


\title{
APPENDIX E
}

READING PASSAGE USED FOR SSI

(Johnson, Darley, and Spriesterbach, 1963)

\author{
ARTHUR, THE YOUNG RAT
}

Once, a long time ago, there was a young rat named Arthur who could never make up his flighty mind. Whenever his swell friends used to ask him to go out to play with them, he would only answer airily, "I don't know." He wouldn't try to say yes, or no either. He would always shirk from making a specific choice.

His proud Aunt Helen scolded him: "Now look here," she stated, "no one is going to aid or care for you if you carry on like this. You have no more mind than a stray blade of grass."

That very night there was a big thundering crash and in the foggy morning some zealous men-with twenty boys and girls-rode up and looked closely at the fallen barn. One of them slipped back a broken board and saw a squashed young rat, quite dead, half in and half out of his hole. Thus, in the end the poor shirker got his just dues. Oddly enough, his Aunt Helen was glad. "I hate such oozy, oily sneaks," said she. 
APPENDIX F

RULES FOR SCORING PHYSICAL CONCOMITANT PORTION OF STUTTERING SEVERITY INSTRUMENT

(Kimba11, 1975)

RULES FOR SCORING PHYSICAL CONCOMMITANT PORTION OF STUTTERING SEVERITY INSTRUMENT

AREA I: DISTRACTING SOUNDS

A. Verbal Junk:

1. Nonsyntactical components

2. Rephrasing

\begin{tabular}{|c|c|}
\hline Score & Erequ/150 \\
\hline 0 & - \\
\hline 1 & 5 \\
\hline 2 & 10 \\
\hline 3 & 15 \\
\hline 4 & 20 \\
\hline 5 & Above \\
\hline
\end{tabular}

B. Audible Breathing:

1. With stuttering occurrence

\begin{tabular}{cc} 
Score* & Percent/Sample \\
\hline 0 & $-\frac{10 \%}{1}-$ \\
$2-$ & $25 \%$ \\
$3-$ & $50 \%$ \\
$4-$ & $75 \%$ \\
$5-$ & Above $75 \%$
\end{tabular}

C. Noises:

1. Whistling

$\frac{\text { Score }}{0}-\frac{\text { Frequ/150 Wds. }}{0}$

2. Popping

$1-1$

3. Clicking

$2-3$

$3-5$

4 . 7

5 - Above 9 
AREA II: FACIAL MOVEMENTS AND/OR TENSION

A. Movements:

1. Tongue, jaws, lips

2. Eyes

$$
\begin{aligned}
& \frac{\text { Score }}{0}-\frac{\text { Frequ/150 Wds. }}{0} \\
& 1-3 \\
& 2 \quad 5 \\
& 3-7 \\
& 4-9 \\
& 5 \text { - Above } 9
\end{aligned}
$$

\begin{tabular}{|c|c|c|}
\hline Score & \# & Erequ/150 Wds. \\
\hline 0 & - & 0 \\
\hline 1 & - & 1 \\
\hline 2 & - & 3 \\
\hline 3 & - & 5 \\
\hline 4 & - & 7 \\
\hline 5 & - & Above 9 \\
\hline
\end{tabular}

\begin{tabular}{|c|c|c|}
\hline Score & & Frequ/150 Wds. \\
\hline 0 & - & 0 \\
\hline 1 & - & 3 \\
\hline 2 & - & 5 \\
\hline 3 & - & 7 \\
\hline 4 & - & . $\quad 9$ \\
\hline 5 & - & Above 9 \\
\hline
\end{tabular}

B. Articulatory Tension :

TOTAL BOTH SUBSECTIONS TO OBTAIN AREA II SCORE

AREA III: HEAD MOVEMENTS AND/OR TENSION

A. Head Movements Only:

B. Head Jerking W/Tension:

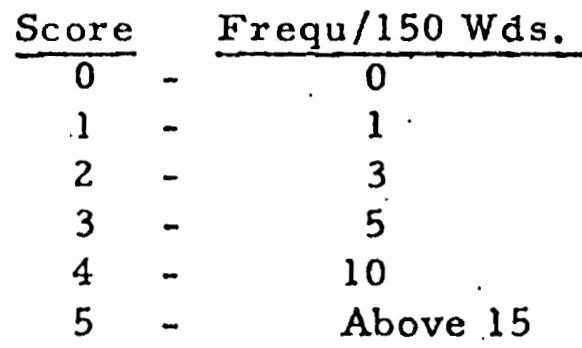

C. Eye Contact:

$\frac{\text { Score }}{0}-\frac{\text { Frequency }}{50-100 \%}$
$3-25-49 \%$
$5-$ Below $25 \%$


AREA IV: EXTREMITIES MOVEMENT

A. Arm, Hand, Torso, Leg Movements: $\frac{\text { Score }^{\circ}}{0}-\frac{\% / 150 \text { Wds. }}{0 \%}$

$1-10 \%$

$2 \quad-25 \%$

$3-50 \%$

$4 \quad-75 \%$

$5 \quad-\quad$ Above $75 \%$

Use subjective judgment and raise 1 point or more depending upon length and degree of audibility.

\#

Use subjective judgment and raise 1 point or more depending upon severity of movement or tense posture.

- Use subjective judgment and raise 1 point or more depending upon degree of tension with the movement and/or degree of amplitude of movement. Points may be added for one or both the se areas. 


$$
\begin{aligned}
& \text { APPENDIX G } \\
& \text { REVISED SEVERITY RATINGS FOR SSI } \\
& \text { PORTLAND STATE UNIVERSITY } \\
& \text { (Kimba11, 1975) } \\
& \text { Severity } \\
& \text { Task Score Description } \\
& 0-8 \text { Normal } \\
& 9-15 \quad \text { Mild } \\
& 16-22 \text {. Moderate } \\
& 23-29 \text { Moderately Severe } \\
& 30-36 \quad \text { Severe } \\
& 37-45 \quad \text { Very Severe }
\end{aligned}
$$


APPENDIX $\mathrm{H}$

COMPOSITE RESEARCH RESULTS

\begin{tabular}{|c|c|c|c|c|c|c|c|}
\hline Subject & $\begin{array}{c}\text { Terms } \\
\text { in } \\
\text { Clinic } \\
\end{array}$ & $\begin{array}{l}\text { Years } \\
\text { out of } \\
\text { Clinic }\end{array}$ & $\begin{array}{c}\text { Stage at } \\
\text { Termination } \\
\end{array}$ & $\begin{array}{c}\text { Baseline } \\
\text { Score } \\
\end{array}$ & $\begin{array}{l}\text { Baseline } \\
\text { Severity }\end{array}$ & $\begin{array}{c}\text { Follow-up } \\
\text { Score } \\
\end{array}$ & $\begin{array}{l}\text { Follow-up } \\
\text { Severity } \\
\end{array}$ \\
\hline$A$ & 1 & 3 & III & 13 & Mild & 5 & Norma 1 \\
\hline B & 2 & 3 & III & 19 & Moderate & 13 & $\operatorname{Mild}$ \\
\hline C & 2 & 1 & IV & 19 & Moderate & 7 & Norma 1 \\
\hline D & 2 & 1 & IV & 22 & Moderate & 19 & Moderate \\
\hline$E$ & 2 & 5 & IV & 7 & Norma 1 & 0 & Norma 1 \\
\hline F & 2 & 1 & III & 27 & Mod. Severe & 10 & Mild \\
\hline$G$ & 2 & 4 & III & 16 & Moderate & 16 & Moderate \\
\hline $\mathrm{H}$ & 2 & 2 & III & 14 & Mild & 1 & Norma 1 \\
\hline I & 2 & 4 & III & 14 & $\operatorname{Mild}$ & 3 & Norma 1 \\
\hline$J$ & 3 & 5 & III & 38 & Very Severe & 26 & Mod. Severe \\
\hline $\mathrm{K}$ & 3 & 4 & SM & 29 & Mod. Severe & 11 & Mild \\
\hline L & 3 & 2 & SM & 22 & Moderate & 8 & Norma 1 \\
\hline$M$ & 3 & 2 & III & 12 & Mild & 10 & Mild \\
\hline $\mathrm{N}$ & 3 & 2 & III & 9 & $\operatorname{Mild}$ & 0 & Norma 1 \\
\hline 0 & 3 & 2 & SM & 16 & Moderate & 3 & Norma 1 \\
\hline $\mathrm{P}$ & 3 & 1 & III & 11 & Mild & 1 & Norma 1 \\
\hline Q & 3 & 2 & III & 26 & Mod. Severe & 3 & Norma 1 \\
\hline $\mathrm{R}$ & 5 & 2 & IV & 6 & Norma 1 & 6 & Normal \\
\hline$S$ & 5 & 1 & III & 28 & Mod. Severe & 0 & Norma 1 \\
\hline $\mathrm{T}$ & 5 & 3 & SM & 19 & Moderate & 7 & NormaI \\
\hline $\mathrm{U}$ & 5 & 1 & SM & 31 & Severe & 37 & Very Severe \\
\hline V & 6 & 4 & SM & 24 & Mod. Severe & 25 & Mcd. Severe \\
\hline
\end{tabular}

